\title{
Occupation and smoking adjusted mortality due to asthma among Swedish men
}

\author{
Kjell Torén, Lars-Gunnar Hörte, Bengt Järvholm
}

\begin{abstract}
The study aims to survey the mortality from asthma in different occupations among Swedish men. The design was a register based cohort study where the smoking adjusted mortality due to asthma among Swedish men 197180 was investigated. For each occupation a smoking adjusted standardised mortality ratio (SMR) was calculated based on a linkage between official mortality statistics 1971-80 and occupational information in the 1970 national census. The information about the smoking habits among different occupations was obtained from a smoking survey carried out in 1963. In the statistical analysis only occupations with more than 10 deaths were considered. A significantly increased mortality from asthma was found among farmers (smoking adjusted SMR 137, 95\% confidence interval (95\% CI) 115-156), farm workers (smoking adjusted SMR 170, 95\% CI 107-235), woodworking machine operators (smoking adjusted SMR 226, 95\% CI 108-344), clerical workers (smoking adjusted SMR 161, 95\% CI 102-220), packers and labellers (smoking adjusted SMR 144, $95 \%$ CI 100-188), and watchmen (smoking adjusted SMR 212, 95\% CI 104320). Exposure to organic dust, such as fresh wood dust and dusts in the farming environment, may cause increased mortality due to asthma.
\end{abstract}

Exposure to many agents is known to cause occupational asthma, and an increased prevalence of asthma in different occupations such as bakers, farmers, and laboratory workers has been reported. Whether an increased prevalence of asthma in different occupations is associated with increased mortality is, however, open to question.

Hence, a longitudinal study of the mortality due to asthma in different occupations would be of interest.

Department of Occupational Medicine, Sahlgrenska Hospital, Göteborg, Sweden

Kjell Torén, Bengt Järvholm

Statistics of Sweden, Stockholm, Sweden

Lars-Gunnar Hörte
One obvious difficulty with such a study is that only highly increased risks are detected as there are so many selection factors, which often leads to underestimation of the risks. ${ }^{1}$ Such selection biases may be diminished, however, by comparing the different occupations with a working population instead of the general population.

Another problem when studying occupational asthma is the possible confounding of smoking. In our study, however, it was possible, to some extent, to estimate this confounding.

The study aims to investigate if an increased mortality due to occupational asthma exists among Swedish men. It is also intended to develop a new aetiological hypothesis concerning occupational asthma.

\section{Subjects and methods}

In Sweden there is a link between mortality data from 1971-1980 and the occupational information obtained in the 1970 National census. Every Swedish inhabitant has a personal identification number making such a link between sets of data feasible. The outcome of interest to us was death from asthma (8th revision of the International Classification of Diseases; 493). ${ }^{2}$ The underlying cause of death according to the classification of death certificates was used.

The study base was all Swedish men between 20 and 64 years old who participated in the 1970 National census. In the census each person reported his occupation in a given week of October 1970. Each occupation was then classified into a three digit code based on the standards from the International Labour Office. ${ }^{3}$ Multiple cohorts were defined according to the occupational titles used in the census. When calculating the expected number of deaths, all Swedish men with an occupation registered in the census were used. The expected numbers of deaths were standardised for age based on comparisons in five year birth cohorts. An unadjusted standardised mortality ratio (SMR) was calculated for each occupation (cohort) as the ratio between the observed and the expected number of deaths $\times 100$. To restrict the number of comparisons the statistical analyses were only carried out in occupations with more than 10 observed cases. Male students and unemployed men were also analysed.

A large survey concerning the smoking habits 
among different occupational groups in Sweden was carried out in 1963 . The sampling fraction was $0.7 \%$ among those aged 18-49 in 1963. The response rate was $94 \%$ after three reminders or a telephone interview. ${ }^{4}$ The occupational classification used was the same as in the 1970 National census. From the smoking survey, it was possible to obtain the percentage of present smokers in different occupational groups among Swedish men aged 18-49 in 1963.

The confounding influence from present smoking was estimated by calculating smoking adjusted SMRs as outlined by Axelson. ${ }^{5}$ The overall incidence, $I$, for asthma could be expressed as $R_{s} I_{o} P_{s}$ $+I_{0} R_{0}\left(1-P_{s}\right)$ where $I_{0}$ is the incidence among nonsmokers and $P_{s}$ is the proportion of smokers in the population, $R_{s}$ is the relative risk for present male smokers of dying from asthma, and $R_{0}$ is the relative risk for non-smokers of dying from asthma. The last is assumed to be unity.

A confounding factor was calculated as the ratio $I / I_{\text {o }}$ for each occupation and $I / I_{0}$ for the reference population. Smoking adjusted SMRs were then calculated as unadjusted SMRs divided by the confounding factor. In the calculations, present smokers were assumed to have a twofold increased mortality due to asthma. ${ }^{67}$ For the smoking adjusted SMR
$95 \%$ confidence intervals ( $95 \%$ CIs) were calculated based on a Poisson distribution. ${ }^{8}$

\section{Results}

The table shows the unadjusted and smoking adjusted SMRs for asthma in all occupational groups with more than 10 cases $(n=32)$. For students, the unadjusted SMR was 213 (95\% CI 115-311) and for the unemployed it was 327 (95\% CI 301-353). The correlation between the unadjusted SMR for asthma and the fraction of present smokers in the different occupations was negative $(r=-0.31)$.

\section{Discussion}

Our study shows an increased mortality due to asthma in six occupations. Among three of themnamely, farmers, farmworkers, and woodworking machine operators the increased risks can probably be assigned to occupational exposures. Among the other three occupations, clerical workers not elsewhere classified (NEC), packers and labellers, and watchmen, the increased risks are probably heavily influenced by selection factors.

The most interesting observation was the

Unadjusted and smoking adjusted SMRs due to asthma in different occupational groups among Swedish men 1971-1980. For the smoking adjusted SMRs the 95\% confidence intervals are given

\begin{tabular}{|c|c|c|c|}
\hline Occupation & No of cases & $\begin{array}{l}\text { Unadjusted } \\
\text { SMR }\end{array}$ & $\begin{array}{l}\text { Smoking adjusted } \\
\text { SMR (95\% CI) }\end{array}$ \\
\hline $\begin{array}{l}\text { Architects } \\
\text { Electrical engineers } \\
\text { Mechanical engineers } \\
\text { Other engineers } \\
\text { Directors and managers } \\
\text { Directors and managers NEC } \\
\text { Bookkeepers } \\
\text { Clerical workers NEC } \\
\text { Working proprietors } \\
\text { Salesmen } \\
\text { Farmers } \\
\text { Farm workers } \\
\text { Loggers } \\
\text { Drivers } \\
\text { Fitter machinists, toolmakers, and machine tool setters } \\
\text { Fitter assemblers and machine erectors } \\
\text { Welders } \\
\text { Metal workers NEC } \\
\text { Electricians } \\
\text { Carpenters } \\
\text { Cabinet makers } \\
\text { Wood working machine operators } \\
\text { Wood workers NEC } \\
\text { Painters } \\
\text { Cement finishers } \\
\text { Printing workers } \\
\text { Bakers } \\
\text { Packers and labellers } \\
\text { Material handling equipment operators } \\
\text { Stock clerks } \\
\text { Watchmen } \\
\text { Building caretakers }\end{array}$ & $\begin{array}{r}19 \\
14 \\
28 \\
15 \\
11 \\
12 \\
13 \\
27 \\
29 \\
21 \\
123 \\
21 \\
21 \\
56 \\
47 \\
34 \\
11 \\
17 \\
18 \\
31 \\
28 \\
13 \\
11 \\
20 \\
28 \\
14 \\
11 \\
43 \\
12 \\
43 \\
13 \\
22\end{array}$ & $\begin{array}{r}73 \\
83 \\
73 \\
112 \\
60 \\
61 \\
81 \\
157 \\
148 \\
86 \\
120 \\
149 \\
76 \\
111 \\
115 \\
104 \\
87 \\
145 \\
94 \\
70 \\
111 \\
217 \\
162 \\
104 \\
76 \\
141 \\
180 \\
147 \\
105 \\
117 \\
200 \\
102\end{array}$ & $\begin{array}{c}75(42-108) \\
87(43-130) \\
74(47-101) \\
109(53-166) \\
59(23-94) \\
65(30-99) \\
78(34-123) \\
161(102-220) \\
150(96-204) \\
83(47-120) \\
137(115-156) \\
170(107-235) \\
81(48-113) \\
107(77-135) \\
117(84-150) \\
103(68-138) \\
83(31-134) \\
145(76-214) \\
96(53-140) \\
72(48-97) \\
115(74-157) \\
226(108-344) \\
172(76-268) \\
104(58-150) \\
75(46-103) \\
137(64-211) \\
194(87-300) \\
144(100-188) \\
100(40-159) \\
119(84-153) \\
212(104-320) \\
105(63-148)\end{array}$ \\
\hline
\end{tabular}

NEC = Not elsewhere classified. 
increased mortality among woodworking machine operators. Wood workers NEC also had an increased mortality due to asthma (smoking adjusted SMR $172,95 \%$ CI 76-268). Both these occupations result in exposure to fresh wood dust, terpenes, and probably also microorganisms. Previously an increased risk of asthma among workers exposed to dust from western red cedar has been reported. ${ }^{9}$ Several case reports describe asthma after exposure to dust from different, mostly exotic, species of tree. ${ }^{9}$

Carpenters showed a significantly decreased mortality due to asthma (smoking adjusted SMR 72, 95\% CI 48-97). By contrast with carpenters, woodworking machine operators work with fresh wood in saw mills. Hence, they are exposed to higher levels of fresh wood dust. This may explain the difference in mortality due to asthma between these groups.

Farmers and farm workers have an increased prevalence of respiratory symptoms..$^{10}$ Risk factors for developing asthma seem to be exposure to storage mites ${ }^{11}$ and pig farming. ${ }^{10}$ Increased mortality due to respiratory diseases has been reported among farmers in Finland. ${ }^{12}$

In the statistical analysis the levels of significance depend in part on the number of observed cases (small populations with highly increased risks will be without significance). In our study, the result for bakers, with the third highest SMR (smoking adjusted SMR 194, 95\% CI 87-300), did not reach statistical significance. On the other hand, the result for farmers, with only a moderately increased SMR (smoking adjusted SMR 137, 95\% CI 115-156) was significant.

Bakers probably have a high prevalence of respiratory symptoms and asthma ${ }^{13}$ and our study indicates that bakers are at increased risk of dying from asthma. It must be realised, however, that the SMRs among the different occupations are not comparable because the standards are the exposed populations.

The smoking survey in 1963 shows that the fraction of present smokers differs considerably between occupational groups. Among farmers there were $37 \%$ present smokers and among rubber workers $75 \%$, indicating an obvious need for smoking adjustment. The interest in smoking as a risk factor for asthma has increased in recent years ${ }^{14}$ and studies indicate a roughly twofold risk for male smokers of developing asthma compared with male nonsmokers ${ }^{67}$ but others have argued for higher risks. ${ }^{15}$ We used a risk of two when calculating the smoking adjusted SMR for asthma.

No data were obtained from the smoking survey about the fraction of ex-smokers. The confounding influence of ex-smoking, however, was probably low. ${ }^{7}$

The negative correlation $(r=-0.31)$ between the fraction of present smokers and asthma indicates that the influence of factors other than smoking, such as occupational exposure or selection forces, was strong. It was also of importance that farmers and farmworkers were two occupations with high unadjusted SMRs and a low proportion of present smokers.

The occupational classification in the study is based on what the persons reported as their usual occupation during one week in 1970, and no data on earlier or later changes in their occupation are available. Occupational changes would tend to reduce any associations between work related exposures and asthma mortality due to non-differential misclassification.

A misclassification of diagnoses between asthma and chronic obstructive pulmonary disease probably also exists. ${ }^{16}$ Furthermore, if both asthma and chronic obstructive pulmonary disease are mentioned on the death certificate, priority was given to chronic obstructive pulmonary disease in the official statistics as an underlying cause of death, regardless of the statement of the death certificate. ${ }^{2}$ Such misclassifications could be regarded as non-differential misclassification. Another bias of importance is that smokers are probably more prone to be diagnosed as having chronic obstructive pulmonary disease instead of asthma just because they are smokers.

When studying chronic diseases, selection bias may be important. Subjects with childhood asthma probably choose physically light occupations, and people who develop asthma as adults probably have a tendency to change occupations towards physically lighter ones. Such mechanisms may explain the increased mortality among clerical workers NEC, packers and labellers, and watchmen.

In conclusion, the present study shows increased mortality due to asthma among several occupational groups. Exposures to fresh wood dust and dusts in the farming environment may account for the increased risks among woodworking machine operators, farmers, and farmworkers.

Requests for reprints to: Dr Kjell Torén, Department of Occupational Medicine, Sahlgrenska Hospital, S:t Sigfridsgatan 85, S-412 66 Göteborg, Sweden.

1 Hernberg S. "Negative" results in cohort studies-how to recognise fallacies. Scand $J$ Work Environ Health 1981;7:(suppl 4):121-6.

2 World Health Organisation. International classification of diseases. Manual of the international statistical classification of diseases, injuries and causes of death. Geneva: WHO, 1967.

3 International Labour Office. International standard classification of occupations. Geneva: ILO, 1958.

4 Rökvanor i Sverige. En postenkätundersökning vàren 1963. (Smoking habits in Sweden. A mail survey-Spring 1963.) Stockholm: Statistiska Centralbyrån, Utredningsinstitutet, 1965. (In Swedish with an English summary.)

5 Axelson $O$. Aspects on confounding in occupational health epidemiology. Scand J Work Environ Health 1978;4:85-9.

6 Kiviloog J, Irnell L, Eklund G. The prevalence of bronchial 
asthma and chronic bronchitis in smokers and non-smokers in a representative local Swedish population. Scandinavian Journal of Respiratory Diseases 1974;55:262-76.

7 Vesterinen E, Kaprio J, Koskenvuo M. Prospective study of asthma in relation to smoking habits among 14729 adults. Thorax 1989;43:534-9.

8 Bailar III J. Significance factors for the ratio of a Poisson variable to its expectation. Biometrics 1964;20:639-43.

9 Goldsmith DF, Shy CM. Respiratory health effects from occupational exposure to wood-dust. Scand J Work Environ Health 1988;14:1-15.

10 Iversen $M$, Dahl $R$, Korsgard J, Hallas T, Jensen EJ. Respiratory symptoms in Danish farmers: an epidemiological study of risk factors. Thorax 1988;43:872-7.

11 Cuthbert OD, Brostoff J, Wraith DG, Brighton WD. "Barn allergy": asthma and rhinitis due to storage mites. Clin Allergy 1979;9:229-36.

12 Notkola V, Husman KH, Laukkanen VJ. Mortality among male farmers in Finland during 1979-83. Scand $J$ Work Environ Health 1987;13:124-8.

13 Editorial. Bakers asthma. $\mathrm{Br}$ Med J 1981;282:678.

14 Editorial. Smoking, occupation and allergic lung disease. Lancet 1985;i:965.

15 Venables KM, Newman Taylor AJ. Prospective study of asthma in relation to smoking habits. Thorax 1989;44:447.

16 American Thoracic Society. Standards for the diagnosis and care of patients with chronic obstructive pulmonary disease (COPD) and asthma. Am Rev Respir Dis 1987;136:225-31.

Accepted 12 November 1990

\section{Vancouver style}

All manuscripts submitted to the $B r J$ Ind Med should conform to the uniform requirements for manuscripts submitted to biomedical journals (known as the Vancouver style).

The $\mathrm{Br} J$ Ind Med, together with many other international biomedical journals, has agreed to accept articles prepared in accordance with the Vancouver style. The style (described in full in $\mathrm{Br}$ Med J, 24 February 1979, p 532) is intended to standardise requirements for authors.

References should be numbered consecutively in the order in which they are first mentioned in the text by Arabic numerals above the line on each occasion the reference is cited (Manson ${ }^{1}$ confirmed other reports $\left.{ }^{2-5} \ldots\right)$. In future references to papers submitted to the $\mathrm{Br} J$ Ind Med should include: the names of all authors if there are six or less or, if there are more, the first three followed by $e t$ al; the title of journal articles or book chapters; the titles of journals abbreviated according to the style of Index Medicus; and the first and final page numbers of the article or chapter.

Examples of common forms of references are:

1 International Steering Committee of Medical Editors. Uniform requirements for manuscripts submitted to biomedical journals. Br Med J 1979;1:532-5.

2 Soter NA, Wasserman SI, Austen KF. Cold urticaria: release into the circulation of histamine and eosino-phil chemotactic factor of anaphylaxis during cold challenge. N Engl J Med 1976;294:687-90.

3 Weinstein L, Swartz MN. Pathogenic properties of invading micro-organisms. In: Sodeman WA Jr, Sodeman WA, eds. Pathologic physiology: mechanisms of disease. Philadelphia: W B Saunders, 1974:457-72. 